Race and the Rhetoric of Resistance 



\title{
Race and the
}

Rhetoric of Resistance

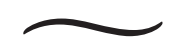

\author{
JEFFREY B. FERGUSON \\ EDITED WITH A FOREWORD BY \\ WERNER SOLLORS \\ AFTERWORD BY \\ GEORGE B. HUTCHINSON
}

\section{[i]}

Rutgers University Press

New Brunswick, Camden, and Newark, New Jersey, and London 
Library of Congress Cataloging-in-Publication Data

Names: Ferguson, Jeffrey B., I964-2018, author. | Sollors, Werner, editor, writer of foreword. | Hutchinson, George, 1953- writer of afterword.

Title: Race and the rhetoric of resistance / by Jeffrey B. Ferguson ; edited and foreword by Werner Sollors ; afterword by George B. Hutchinson.

Description: New Brunswick, New Jersey : Rutgers University Press,

[202I] | Includes bibliographical references and index.

Identifiers: LCCN 2020027847 | ISBN 9781978820838 (hardcover) |

ISBN 978197882082I (paperback) | ISBN 9781978820845 (epub) |

ISBN 9781978820852 (mobi) | ISBN 9781978820869 (pdf)

Subjects: LCSH: African Americans-Historiography. | African

Americans-Study and teaching-United States. | American literature-

African American authors-History and criticism. | United States-

Race relations-Historiography.

Classification: LCC Er84.65 .F47 202I | DDC 973/.04960730072-dc23

LC record available at https://lccn.loc.gov/2020027847

A British Cataloging-in-Publication record for this book is available from the British Library.

For permissions credits, please refer to the Editor's Acknowledgments.

Copyright (C) 202I by Jeffrey B. Ferguson

Foreword copyright (C) 202I by Werner Sollors

Afterword copyright (C) 202I by George B. Hutchinson

All rights reserved

No part of this book may be reproduced or utilized in any form or by any means, electronic or mechanical, or by any information storage and retrieval system, without written permission from the publisher. Please contact Rutgers University Press, ro6 Somerset Street, New Brunswick, NJ o89or.

The only exception to this prohibition is "fair use" as defined by U.S.

copyright law.

The paper used in this publication meets the requirements of the American National Standard for Information Sciences-Permanence of Paper for Printed Library Materials, ANSI Z39.48-I992.

www.rutgersuniversitypress.org

Manufactured in the United States of America 
For Agustina, Django, and Ted 
